\title{
Liver enzymes activity in periparturient high and low yielding Sahiwal and Karan Fries Cows during summer and winter season
}

\author{
MM Vaidya ${ }^{1}$ and SV Singh ${ }^{2}$
}

Received: 27 July 2019 / Accepted: 08 August 2019 / Published online: 27 August 2019

(c) Indian Dairy Association (India) 2019

\begin{abstract}
Ten each of pregnant Sahiwal and Karan Fries cows were selected from Livestock Research center, ICAR-NDRI, Karnal (Haryana) during summer and winter season separately. These animals were further divided equally ( 5 each) into two groups i.e. high and low producing. All the animals were maintained under existing feeding and management system followed at the farm. To quantify the effects of thermal and metabolic stress on liver enzymes (alkaline phosphatase and Lactate dehydrogenase), blood samples were collected from periparturient high and low producing Sahiwal and Karan Fries cows on days -45, -30, -15 (before calving), and 15,30, and 45 (After calving) with respect to day of parturition (0) . The results showed that the alkaline phosphatase (ALP) activity in the blood plasma of high and low yielding Sahiwal cows decreased by 5.6 and $7.6 \%$ and in Karan Fries the decline was 10.8 and $4.7 \%$ on the day of calving from the pre calving values (45 days) respectively during the summer season. During winter season the ALP activity in blood plasma of high and low yielding Sahiwal cows decreased by 19.7 and $12.8 \%$ on $30^{\text {th }}$ and $15^{\text {th }}$ day of calving, where as in Karan Fries cows the activity decreased by 13.9 and $9.75 \%$ on $15^{\text {th }}$ day of postpartum and on the day of calving from the pre-calving values
\end{abstract}

MM Vaidya ${ }^{1}$ and SV Singh ${ }^{2}(\bowtie)$

${ }^{1}$ Assistant Professor, College of Veterinary and Animal Sciences Udgir, Maharashtra, India

Email: mangeshvd378@gmail.com

${ }^{2}$ Animal Physiology Division National Dairy Research Institute,

Karnal Haryana, India

Email: sohanvir2011@gmail.com
(45 days) respectively. The magnitude of increase in Lactate dehydrogenase (LDH) activity was higher on $15^{\text {th }}$ day postpartum compared to pre and post calving period in high and low yielding groups of both the breeds. The plasma activity of LDH in high and low yielding Sahiwal cows increased by 17.7 and $12.6 \%$ on the day of calving from the pre-calving values (45days) respectively during the summer season. During the winter season, the plasma LDH activity in high and low yielding Sahiwal cows increased by 43.7 and $48 \%$ respectively on the $15^{\text {th }}$ day of calving from the pre calving values (45 days). The results showed the significantly higher activity of both the enzymes (ALP and LDH) in Karan Fries cows, higher yielders and during summer compared to Sahiwal, low yielders and winter season, respectively, indicated that higher yielding cows (specially Karan Fries) showed be protected from heat stress for sustain milk production.

Keywords: Alkaline phosphatase, Karan Fries, Lactate dehydrogenase, Periparturient, Sahiwal

\section{Introduction}

All organisms occasionally or regularly are being exposed to thermal and metabolic stress. Alkaline phosphatase (ALP) is an enzyme synthesized in the liver, bone, and the placenta. In general, the ALP present in high concentrations in growing bone and bile. Abnormally high levels of blood ALP may indicate disease in the liver, bile duct obstruction, heat stress, etc. The major physiological role of ALP is to regulate cell division and growth. ALP also involves in the transport of metabolites through the cell membrane (Swarup et al. 1981). Plasma ALP activity increased in the feed restricted heifers in a thermoneutral environment associated with an increased liver activity to support the classic metabolism of reduced dry matter intake in cattle. Plasma ALP activity decreased during hotter periods of the summer and the subsequent recovery was not complete (Abeni et al. 2007). Whereas, lactate dehydrogenase (LDH) is a cytoplasmic enzyme, which converts pyruvic acid into lactic acid. Benjamin (1961) showed an association of LDH enzyme activity with cellular damage. During late pregnancy, the feed intake of ruminants reduced despite an increased nutrient requirement for fetal development and mammogenesis/lactogenesis (Ingvartsen et al. 1992). This down-regulation of the appetite is probably caused 
by, an initial mobilization of lipid from body deposits and reduction of rumen capacity as a result of the growing fetus (Ingvartsen et al. 1999 and Ingvartsen and Andersen, 2000). De Coen et al. (2001) observed that LDH is a terminal enzyme of anaerobic glycolysis, therefore, being of crucial importance to the muscular physiology, particularly in conditions of chemical stress, when high levels of energy may be required in a short period. Biochemical and molecular parameters that are specific and sensitive may be useful for identifying doses below which increases in biomarkers are not statistically significant (Andersen and Barton, 1998). The information related to the activities of both the enzymes during summer and winter stress in high and low yielding cows is scanty. Therefore, the present study was undertaken to find out the levels of these enzymes during different seasons, breeds and production levels.

\section{Materials and Methods}

The present study was conducted in ICAR-NDRI, Karnal. The Experimental animals were maintained as per the standard conditions of feeding and management at Livestock Research center of ICAR-NDRI, Karnal. All the pregnant cows were fed a ration consisting of roughages (berseem, oats, maize or jowar fodder) as per the availability at the farm and concentrate mixture consisted of mustard cake, wheat bran, rice bran, mineral mixture and salt. Throughout the experimental period cows were given concentrate mixture at $8.30 \mathrm{AM} @$ of $1 \mathrm{~kg} / \mathrm{cow} / \mathrm{day}$, then $1.5 \mathrm{~kg} /$ cow/day up to 15 days before calving. After calving, the cows were given concentrate mixture @ 1 kg/2.5 kg of milk production. Fresh tap water was available for drinking to all the animals round the clock. Environmental variables were recorded during the study and data have been presented in table 1 .

Blood samples were collected from periparturient high and low producing Sahiwal and Karan Fries cows at fortnightly interval i.e. on days $-45,-30,-15$ (before calving), and 15,30 , and 45 (After calving) concerning the day of parturition (0) using vacutainers.
Plasma was separated by centrifuging the blood samples at $3000 \mathrm{rpm}$ for 30 minutes. Plasma samples were analyzed for the activity of liver enzymes during summer and winter season in high and low producing Sahiwal and Karan Fries cows.

\section{Alkaline phosphatase (AKP)}

Alkaline phosphatase was estimated in blood plasma samples by conversion of phenyl phosphate to inorganic phosphate and phenol at $\mathrm{pH} 10$. Phenol so formed reacts in alkaline medium with 4-Aminoantipyrine in the presence of the oxidizing agent Potassium Ferricyanide and forms an Orange red-colored colored complex, which can be measured calorimetrically. The color intensity is proportional to the enzyme activity. Alkaline phosphatase activity was calculated by using Kind and Kings method and kits provided by Span Diagnostics Ltd., India.

Mixed well after the addition of each reagent and measured O.D. of Blank, Standard, Control, and the Test against distilled water using a green filter or at $510 \mathrm{~nm}$. UV-Spectrophotometer (Bio-Age 756PC) was programmed as per assay parameters. The analyzer was blanked with double distilled water. Absorbance was recorded after 30 seconds. Reading was repeated after every 30 seconds i.e. up to 120 seconds at $405 \mathrm{~nm}$ and $\mathrm{A} /$ minute was determined.

\section{Lactate dehydrogenase (LDH)}

Lactate dehydrogenase was estimated in blood plasma samples using Optimized DGKC, kinetic assay kits (Span Diagnostics Ltd., India). LDH catalyzes the conversion of pyruvate to lactate with simultaneous oxidation of reduced NADH to NAD. The rate of change in absorbance due to the formation of NAD is measured at $340 \mathrm{~nm}$ and is proportional to the LDH activity in the sample.

\section{Statistical analysis}

Table 1 Environmental parameters recorded during summer and winter season

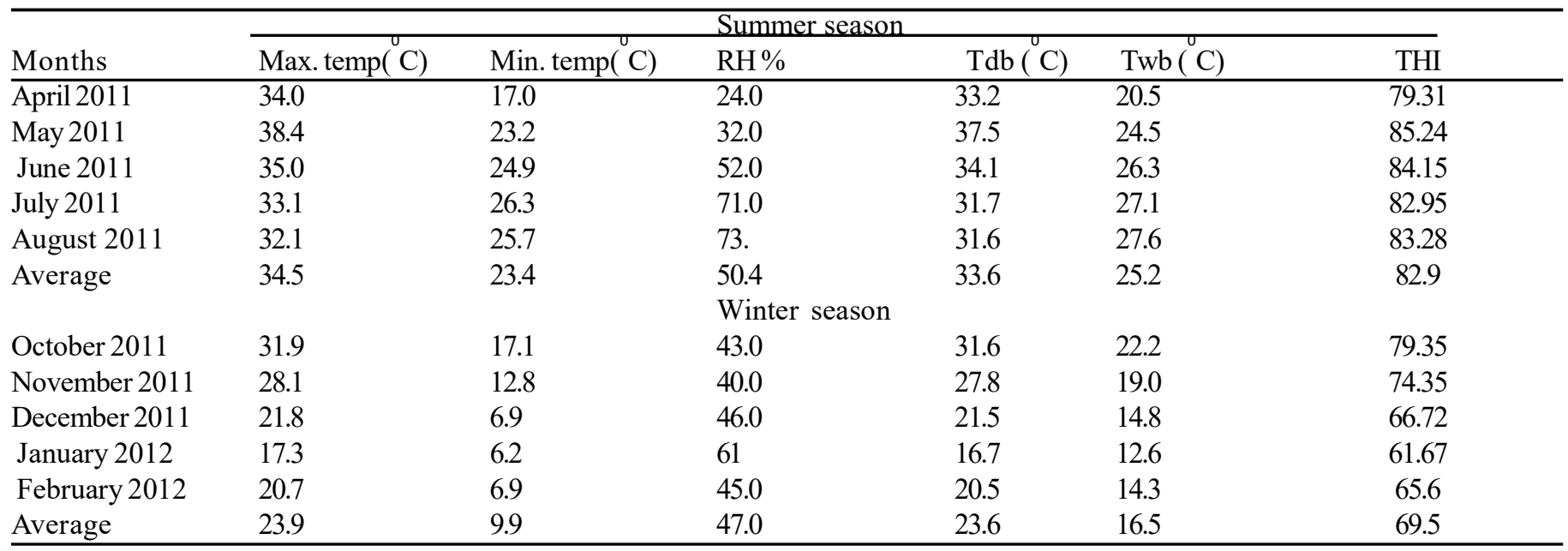


The data were analyzed using SAS software, version 9.1 of SAS system for window, copyright $C$ (2011), SAS Institute Inc., Cary, $\mathrm{NC}$, USA for means, standard error and analysis of variance among different parameters during summer and winter season.

\section{Results and Discussion}

During the summer season, the activity of alkaline phosphatase (ALP) in the blood plasma of high and low yielding Sahiwal cows were $24.8 \pm 0.23$ and $26.3 \pm 0.30 \mathrm{KAUnit}$ on $45^{\text {th }}$ day of prepartum and the activity decreased to $23.4 \pm 0.22$ and $24.3 \pm 0.33$ KAUnit on the day of calving respectively. In high and low yielding Karan Fries cows the activity of ALP was $25.0 \pm 0.48$ and $23.0 \pm 0.24$ KAUnit on $45^{\text {th }}$ day of prepartum and the activity decreased to $22.3 \pm 0.35$ and $21.9 \pm 0.16 \mathrm{KAUnit}$ respectively on the day of calving from the pre calving values during the summer season. (Table 2) Abeni et al. (2007) indicated ALP activity as a quick and reliable blood marker for heat stress. Marai et al. (1997) also observed an increase in alkaline phosphatase activity in high ambient temperatures during summer.

The plasma activity of ALP in high and low yielding Sahiwal cows decreased by 5.6 and $7.6 \%$ and in Karan Fries decreased by 10.8 and $4.7 \%$ on the day of calving from the pre calving values (45 day) respectively during summer season (Table 2 ). The activity of ALP were significantly $(\mathrm{P}<0.01)$ different among both the groups (high and low yielding) of Sahiwal and Karan Fries cows (Table 3). Ronchi et al. (1999) observed a reduction of ALP in heifers during stressful conditions. Similarly, Abeni et al. (2007) reported that the lower plasma ALP activity would coincide with a reduction in liver activity in cows exposed to high temperatures. During the winter season, the activity of alkaline phosphatase in the blood plasma of high and low yielding Sahiwal cows were $14.2 \pm 0.50$ and $13.2 \pm 0.22$ KAUnit on $45^{\text {th }}$ day of prepartum and the ALP activity decreased to $11.4 \pm 0.51$ and $11.5 \pm 0.27$ KAUnit on $30^{\text {th }}$ and $15^{\text {th }}$ day postpartum from the pre calving values (45 days) respectively. (Table $2 \& 3$ ). In high and low yielding Karan Fries cows the activity of ALP were 12.9 \pm 1.26 and $12.3 \pm 0.30$ KAUnit on $45^{\text {th }}$ day of prepartum and the activity decreased to $11.1 \pm 0.69$ and $11.1 \pm 0.42 \mathrm{KAUnit}$ on the $15^{\text {th }}$ day postpartum and the day of calving respectively during the winter season. The plasma activity of alkaline phosphatase in high and low yielding Sahiwal cows decreased by 19.7 and $12.8 \%$ on $30^{\text {th }}$ and $15^{\text {th }}$ day postpartum and in Karan Fries the values decreased by 13.9 and $9.75 \%$ on the $15^{\text {th }}$ day postpartum and day of calving from the pre calving values (45 day) respectively during winter season (Table 2 ). The activity of plasma alkaline phosphatase were significantly $(\mathrm{P}<0.05)$ different in both the groups of Sahiwal and Karan Fries (Table 3) . The results of the present study are in general agreement with those of Khushwaha (2011) who reported significantly $(\mathrm{P}<0.05)$ lower mean values of ALP during winter compared to the summer season in Karan Fries cattle. The least square mean values in Sahiwal and Karan Fries; during summer and winter season and in high and low yielding groups were $18.73 \pm 0.36$ and $17.89 \pm 0.63$ KAUnit; $24.19 \pm 0.34$ and $12.43 \pm 0.66 \mathrm{KAUnit}$ and $18.35 \pm 0.56$ and

Table 2 Plasma alkaline phosphatase activity (KA Unit) in periparturient Sahiwal and Karan Fries cows during summer and winter season

\begin{tabular}{|c|c|c|c|c|c|c|c|c|}
\hline \multirow{3}{*}{$\begin{array}{l}\text { Season } \\
\text { Breed } \\
\text { Days }\end{array}$} & \multicolumn{3}{|c|}{ Summer } & \multicolumn{4}{|c|}{ Winter } & \multirow[b]{3}{*}{ LY } \\
\hline & Sahiwal & & Karan Fries & & Sahiwal & & Karan Fries & \\
\hline & $\mathrm{HY}$ & LY & $\mathrm{HY}$ & LY & HY & LY & HY & \\
\hline 45 & $24.8 \pm 0.23^{\mathrm{a}}$ & $26.3 \pm 0.30^{\mathrm{a}}$ & $25.0 \pm 0.48^{\mathrm{a}}$ & $23.0 \pm 0.24^{\mathrm{a}}$ & $14.2 \pm 0.50^{\mathrm{a}}$ & $13.2 \pm 0.22^{\mathrm{a}}$ & $12.9 \pm 1.26^{\mathrm{a}}$ & $12.3 \pm 0.30^{\mathrm{a}}$ \\
\hline-15 & $24.3 \pm 0.25^{\mathrm{ba}}$ & $25.2 \pm 0.47^{\mathrm{ba}}$ & $24.4 \pm 0.27^{\mathrm{ba}}$ & $22.9 \pm 0.26^{\mathrm{ba}}$ & $13.5 \pm 0.54^{\mathrm{ba}}$ & $13.3 \pm 0.46^{\mathrm{ba}}$ & $12.1 \pm 0.85^{\text {ba }}$ & $13.7 \pm 1.39^{\mathrm{ba}}$ \\
\hline 0 & $23.4 \pm 0.22^{\mathrm{c}}$ & $24.3 \pm 0.33^{c}$ & $22.3 \pm 0.35^{\mathrm{c}}$ & $21.9 \pm 0.16^{\mathrm{c}}$ & $11.8 \pm 0.45^{\mathrm{c}}$ & $11.6 \pm 0.39^{c}$ & $12.5 \pm 1.39^{c}$ & $11.1 \pm 0.42^{\mathrm{c}}$ \\
\hline 45 & $25.1 \pm 0.38^{\mathrm{ba}}$ & $25.9 \pm 0.27^{\mathrm{ba}}$ & $23.7 \pm 0.77^{\text {ba }}$ & $23.2 \pm 0.51^{\mathrm{ba}}$ & $11.6 \pm 0.59^{\text {ba }}$ & $12.4 \pm 0.35^{\text {ba }}$ & $12.9 \pm 1.00^{\text {ba }}$ & $12.1 \pm 0.42^{\text {ba }}$ \\
\hline
\end{tabular}

The values are the mean and SEM of five observations on five animals.

The columns with similar superscripts do not differ significantly

Table 3 Plasma ALP activity (KA unit) during periparturient period with respect to breed, season and groups

\begin{tabular}{llllllllll}
\hline Effects & Days & -45 & -30 & -15 & 0 & 15 & 30 & 45 & O.Mean \pm SE \\
\hline Breed & Sahiwal & 19.63 & 19.18 & 19.09 & 17.78 & 18.16 & 18.52 & 18.72 & $18.73 \pm 0.36^{\mathrm{a}}$ \\
& Karan Fries & 18.31 & 18.71 & 18.26 & 16.95 & 16.95 & 18.09 & 17.97 & $17.89 \pm 0.63^{\mathrm{b}}$ \\
Season & Summer & 24.80 & 24.50 & 24.22 & 22.98 & 23.76 & 24.60 & 24.46 & $24.19 \pm 0.34^{\mathrm{a}}$ \\
& Winter & 13.14 & 13.39 & 13.14 & 11.76 & 11.35 & 12.00 & 12.23 & $12.43 \pm 0.66^{\mathrm{b}}$ \\
Group & High Yielding & 19.24 & 19.17 & 18.57 & 17.51 & 17.43 & 18.24 & 18.31 & $18.35 \pm 0.56^{\mathrm{a}}$ \\
& Low Yielding & 18.70 & 18.72 & 18.79 & 17.23 & 17.69 & 18.36 & 18.38 & $18.27 \pm 0.43^{\mathrm{a}}$ \\
\hline
\end{tabular}

Overall least square means with similar superscripts do not differ significantly from each other for particular effects 
Table 4 Plasma lactate dehydrogenase activity (U/l) in periparturient Sahiwal and Karan Fries cows during summer and winter season

\begin{tabular}{|c|c|c|c|c|c|c|c|c|}
\hline \multicolumn{3}{|c|}{ Season } & \multicolumn{4}{|l|}{ Summer } & \multicolumn{2}{|l|}{ Winter } \\
\hline Breed & Sahiwal & & Karan Fries & & Sahiwal & & Karan Fries & \\
\hline Days & HY & LY & HY & LY & HY & LY & HY & LY \\
\hline 45 & $345.2 \pm 12.3^{\mathrm{e}}$ & $372.1 \pm 14.1^{\mathrm{e}}$ & $349.3 \pm 15.9^{\mathrm{e}}$ & $339.3 \pm 15.6^{\mathrm{e}}$ & $190.8 \pm 6.0^{\mathrm{e}}$ & $195.0 \pm 3.3^{\mathrm{e}}$ & $208.8 \pm 16.9^{\mathrm{e}}$ & $213.8 \pm 9.2^{\mathrm{e}}$ \\
\hline-30 & $366.2 \pm 6.8^{\mathrm{de}}$ & $389.5 \pm 6.2^{\mathrm{de}}$ & $355.7 \pm 18.1^{\mathrm{de}}$ & $372.6 \pm 10.9^{\text {de }}$ & $203.8 \pm 10.1^{\text {de }}$ & $216.0 \pm 5.2^{\mathrm{de}}$ & $229.2 \pm 18.0^{\text {de }}$ & $216.6 \pm 13.6^{\text {de }}$ \\
\hline-15 & $386.3 \pm 3.9^{\mathrm{bc}}$ & $396.7 \pm 17.7^{b c}$ & $377.6 \pm 12.5^{\mathrm{bc}}$ & $400.3 \pm 9.9^{\mathrm{bc}}$ & $228.2 \pm 9.2^{\mathrm{bc}}$ & $244.4 \pm 3.6^{\mathrm{bc}}$ & $255.2 \pm 21.2^{\mathrm{bc}}$ & $249.6 \pm 9.7^{\mathrm{bc}}$ \\
\hline 0 & $406.4 \pm 3.5^{\mathrm{a}}$ & $419.1 \pm 8.0^{\mathrm{a}}$ & $418.3 \pm 13.9^{\mathrm{a}}$ & $435.0 \pm 14.6^{\mathrm{a}}$ & $258.2 \pm 8.1^{\mathrm{a}}$ & $273.0 \pm 3.3^{\mathrm{a}}$ & $288.8 \pm 15.3^{\mathrm{a}}$ & $279.2 \pm 7.0^{\mathrm{a}}$ \\
\hline 15 & $403.1 \pm 4.0^{\mathrm{a}}$ & $398.2 \pm 15.3^{\mathrm{a}}$ & $419.4 \pm 8.2^{\mathrm{a}}$ & $402.9 \pm 6.5^{\mathrm{a}}$ & $274.2 \pm 8.8^{\mathrm{a}}$ & $288.6 \pm 6.8^{\mathrm{a}}$ & $309.2 \pm 9.7^{\mathrm{a}}$ & $302.4 \pm 6.5^{\mathrm{a}}$ \\
\hline 30 & $389.2 \pm 1.0^{\mathrm{ba}}$ & $389.4 \pm 2.9^{\text {ba }}$ & $414.2 \pm 4.7^{\mathrm{ba}}$ & $405.1 \pm 3.9^{\mathrm{ba}}$ & $250.8 \pm 10.1^{\mathrm{ba}}$ & $256.2 \pm 16.6^{b a}$ & $295.2 \pm 12.8^{\text {ba }}$ & $252.4 \pm 20.8^{\text {ba }}$ \\
\hline 45 & $375.5 \pm 6.3^{\mathrm{dc}}$ & $359.1 \pm 13.2^{\mathrm{dc}}$ & $361.7 \pm 15.5^{\mathrm{dc}}$ & $363.5 \pm 17.1^{\mathrm{dc}}$ & $226.0 \pm 8.3^{\mathrm{dc}}$ & $222.8 \pm 11.2^{\mathrm{dc}}$ & $279.6 \pm 10.8^{\mathrm{dc}}$ & $248.6 \pm 13.5^{\mathrm{dc}}$ \\
\hline
\end{tabular}

The values are the mean and SEM of five observations on five animals.

The columns with similar superscripts do not differ significantly

Table 5 Plasma LDH activity (U/l) during periparturient period with respect to breed, season and groups

\begin{tabular}{|c|c|c|c|c|c|c|c|c|c|}
\hline Effects & Days & -45 & -30 & -15 & 0 & 15 & 30 & 45 & O.Mean \pm SE \\
\hline \multirow[t]{2}{*}{$\overline{\text { Breed }}$} & Sahiwal & 275.8 & 293.9 & 313.9 & 339.2 & 341.0 & 321.4 & 295.8 & $311.6 \pm 8.06^{\mathrm{a}}$ \\
\hline & Karan Fries & 277.8 & 293.5 & 320.7 & 355.3 & 358.5 & 341.7 & 313.4 & $323.0 \pm 12.58^{b}$ \\
\hline \multirow[t]{2}{*}{ Season } & Summer & 351.5 & 371.0 & 390.2 & 419.7 & 405.9 & 399.5 & 364.9 & $386.1 \pm 10.09^{\mathrm{a}}$ \\
\hline & Winter & 202.1 & 216.4 & 244.4 & 274.8 & 293.6 & 263.7 & 244.3 & $248.5 \pm 10.55^{\mathrm{b}}$ \\
\hline \multirow[t]{2}{*}{ Group } & High Yielding & 273.5 & 288.7 & 311.8 & $342.9 \pm$ & 351.5 & 337.4 & 310.7 & $316.6 \pm 10.43^{\mathrm{a}}$ \\
\hline & Low Yielding & 280.0 & 298.7 & 322.7 & 351.6 & 348.0 & 325.8 & 298.5 & $317.9 \pm 10.22^{\mathrm{a}}$ \\
\hline
\end{tabular}

Overall least square means with similar superscripts do not differ significantly from each other for particular effects

$18.27 \pm 0.43 \mathrm{KAUnit}$ respectively. The least square mean activity of ALP lowered to 4.4 in Karan Fries cows compared to Sahiwal cows. The least square mean activity of ALP lowered to $48.6 \%$ during summer season compared to the winter season. In high producing groups of cattle the plasma ALP activity lowered by $0.4 \%$ compared to low yielder groups. The overall activity of ALP differed significantly $(\mathrm{P}<0.05)$ between breeds and season (Table 3).

\section{Lactate dehydrogenase}

During summer season, the activity of plasma LDH in high and low yielding Sahiwal cows were $345.2 \pm 12.3$ and $372.1 \pm 14.1 \mathrm{U} / 1$ on $45^{\text {th }}$ day of prepartum and the activity increased to $406.4 \pm 3.5$ and $419.1 \pm 8.0 \mathrm{U} / \mathrm{l}$ on the day of calving respectively. In high and low yielding Karan Fries cows the plasma LDH activity was $349.3 \pm 15.9$ and $339.3 \pm 15.6 \mathrm{U} / 1$ on $45^{\text {th }}$ day of prepartum and increased to $419.4 \pm 8.2$ and $435.0 \pm 14.6 \mathrm{U} / 1$ on $15^{\text {th }}$ day postpartum and day of calving respectively (Table $4 \& 5$ ). Findings of the present study are in accordance with those of Okab et al. (2008) who reported higher activity $\mathrm{LDH}(2.61 \pm 0.06 \mathrm{IU} / \mathrm{L})$ enzyme during summer compared to spring ( $2.32 \pm 0.10 \mathrm{IU} / \mathrm{L})$ season. Kachmar and Moss (1976) signify the importance of LDH as an indicator of anemia, renal stress, muscular dystrophy as well as liver damage. An increase in LDH activity indicates the deterioration of different tissue functions suffering from heat stress. Khushwaha (2011) showed higher values of lactate dehydrogenase in Karan Fries during different seasons but the magnitude of increase was higher during the summer season among different breeds of cattle. The plasma activity of lactate dehydrogenase in high and low yielding Sahiwal cows increased by 17.7 and $12.6 \%$ on the day of calving and in Karan Fries the activity of LDH increased by 20.06 and $28.2 \%$ on the $15^{\text {th }}$ day postpartum and day of calving from the pre calving values ( 45 day) respectively during summer season (Table $4 \& 5$ ). The lactate dehydrogenase activity were significantly $(\mathrm{P}<0.05)$ different in both the groups of Sahiwal and Karan Fries cows. Antunovic et al. (2011) also found significantly higher LDH activity in the blood of ewes during lactation compared to pregnant. Greenfield et al. (2000) suggested that changes in the activity of these enzymes may be related to reduced dry matter intake around parturition and that may lead to hepatic lipidosis to alter the normal functions of the liver. During winter season, the activity of plasma lactate dehydrogenase in high and low yielding Sahiwal cows were $190.8 \pm 6.0$ and $195.0 \pm 3.3 \mathrm{U} / 1$ on $45^{\text {th }}$ day of prepartum and the activity increased to $274.2 \pm 8.8$ and $288.6 \pm 6.8 \mathrm{U} / 1$ on the $15^{\text {th }}$ day of calving respectively. In high and low yielding Karan Fries cows the activity of lactate dehydrogenase was $208.8 \pm 16.9$ and $213.8 \pm 9.2 \mathrm{U} / 1$ on $45^{\text {th }}$ day of prepartum and the activity increased to $309.2 \pm 9.7$ and $302.4 \pm 6.5$ on $30^{\text {th }}$ day postpartum respectively during the winter season. (Table $4 \& 5$ ). The plasma activity of lactate dehydrogenase in high and low yielding Sahiwal cows increased by 43.7 and $48 \%$ and in Karan Fries the activity of LDH increased by 48 and $41.4 \%$ respectively on $15^{\text {th }}$ day of calving from the pre calving values during the winter season (Table $4 \&$ 5).The plasma lactate dehydrogenase activity were significantly 
$(\mathrm{P}<0.01)$ different in both the groups of high and low yielding Sahiwal and Karan Fries cow. The least square mean values of LDH in Sahiwal and Karan Fries cows during summer and winter season and in high and low yielding groups were 311.6 \pm 8.06 and $323.0 \pm 12.58 \mathrm{U} / 1 ; 386.1 \pm 10.09$ and $248.5 \pm 10.55 \mathrm{U} / 1$ and $316.6 \pm 10.43$ and $317.9 \pm 10.22 \mathrm{U} / 1$ respectively (Table5). The least square mean activity of LDH increased by $49.4 \%$ in Karan Fries cows compared to Sahiwal cows. The least square mean activity of LDH increased by $55.3 \%$ during summer season compared to the winter season. In low yielding groups of both the breed, the LDH activity increased by $0.4 \%$ compared to high yielders groups. The overall mean values of LDH differed significantly $(\mathrm{P}<0.05)$ between breeds and seasons (Table 5).

\section{Conclusions}

The ALP activity was lower $(\mathrm{P}<0.05)$ during winter season compared to summer season on the day of calving compared to precalving values (45 days). The ALP activity was lower $(\mathrm{P}<0.05)$ in both the groups of the high yielders cows compared to low yielder on the day of calving compared to precalving values $(45$ day). The plasma LDH activity increased significantly $(\mathrm{P}<0.05)$ on the day of calving in both the breeds, seasons and groups, but the magnitude of increase in LDH activity was higher $(\mathrm{P}<0.05)$ on $15^{\text {th }}$ day of postpartum in high yielders compared to low yielders group. Therefore, the study concludes that there might be a oxidative stress in the high yielders compared to low yielders and more marked in Karan Fries cows compared to Sahiwal. Therefore, both the groups of cows required protection during extreme climatic conditions, but the high yielders group will require extra protection during the climate change scenario in the future. Therefore, special care needs to be given to the high yielders, Karan Fries cows and during summer for sustained productivity.

\section{Acknowledgments}

The authors are thankful to the Director, ICAR-NDRI, Karnal for providing necessary funds and facilities for completing the research work.

\section{References}

Abeni F, Calamari L, Stefanini L (2007) Metabolic condition of lactating dairy cows during the hot season in the Po Valley. 1. Blood indicators of heat stress. Int J Biometeorol 52: 87-96
Andersen ME, Barton HA (1998) The use of biochemical and molecular parameters to estimate dose response relationships at low levels of exposure. Environ Health Perspect 1: 349-355

Antunovic Z, Novoselec J, Sauerwein HM, Speranda M, Vegara, PV (2011) Blood metabolic profile and some of hormones concentration in ewes during different physiological status. Bulgarian J Agri Sci 17: 687-695

Benjamin MM (1961) Outline of veterinary clinical pathology 2nd Edition. Iowa state Univ Press Ames 38-42

Broucek J, Kovalcikova M, Kovalcik K (1986) The effect of high temperatures on feed intake, milk production and biochemical traits. Proc 37th Annual Meeting of EAAP, 1: 596-597

De Coen WM, Jansen CR, Segner H (2001) The use of biomarkers in Daphnia magna toxicity testing V. In vivo alternations in the carbohydrate metabolism of Daphnia magna exposed to sublethal concentrations of mercury and lindane. Ecotoxicol Environ Safety 48: $223-234$

Greenfield RB, Cecava MJ, Johnson TR, Donkin SS (2000) Impact of dietary protein amount and rumen undegradability on intake, peripartum liver triglyceride, plsama metabolites and milk production in transition dairy cattle. J Dairy Sci 83:703-710

Ingvartsen KL (1992) Virkning af græsmarksafgrøders konservering og tørstofindhold $\mathrm{p}^{\circ}$ a ungdyrs foderoptagelse, tilvækst og foderudnyttelse: En oversigt. Report 711. Danish Institute of Animal Science, Research Centre Foulum: 1-44

Ingvartsen KL, Andersen JB (2000) Integration of metabolism and intake regulation: a review focusing on periparturient animals. J Dairy Sci 83: $1573-1597$

Ingvartsen KL, Boisclair Y (2001) Leptin and the regulation of food intake, energy homeostasis and immunity with special focus on periparturient ruminants. Domest Anim Endocrinol 21: 215-250

Kachmar, JF, Moss DW (1976) Enzymes, in: Tietz NW, Fundamentals of Clinical Chemistry Philadelphia, USA. : WB Sanders Company: 653654

Khushwaha (2011) Influence of temperature variability on Physiological, hematological and biochemical profile of growing and adult cattle and buffalo. MVSc Thesis submitted to National Dairy Research Institute, Karnal Haryana.

Marai IFM, Daader AM, Abdel Samee AM, Ibrahim H (1997) Winter and summer effects and their amelioration on lactating Friesian and Holstein cows maintained under Egyptian conditions. Proceedings of the International Conference on Animal, Poultry, Rabbits and Fish Production and Health, Cairo, Egypt.

Okab AB, El Banna SG, Koriem, AA (2008) Influence of environmental temperatures on some Physiological and Biochemical Parameters of New-Zealand Rabbit Males. Slovak. J Anim Sci 41: 12 - 19

Ronchi B, Bernabucci U, Lacetera N, Verini Supplizi A, Nardone A (1999) Distinct and common effects of heat stress and restricted feeding on metabolic status of Holstein heifers. Zootecnica e Nutrizione Animale 25: $11-20$

Swarup G, Cohen S, Grabers DL (1981) Selective dephosphorylation of proteins containing phosphotyrosine by alkaline phosphatases. J Biol Chem 256:8197-8201 